\title{
Simulating Potential Switchgrass Production in the United States
}

Allison M. Thomson, R. César Izarrualde, Tristram O. West, David J. Parrish, Donald D. Tyler, Jimmy R. Williams

December 2009

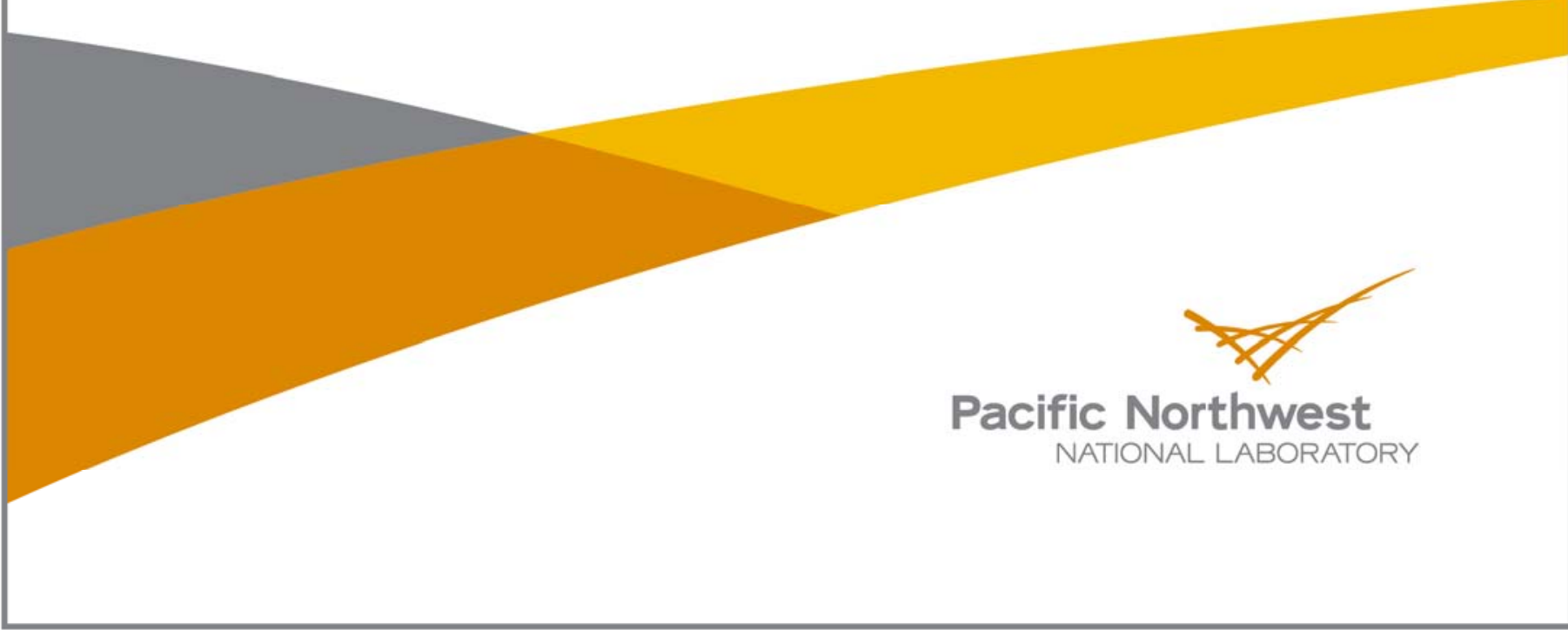




\title{
DISCLAIMER
}

This report was prepared as an account of work sponsored by an agency of the United States Government. Neither the United States Government nor any agency thereof, nor Battelle Memorial Institute, nor any of their employees, makes any warranty, express or implied, or assumes any legal liability or responsibility for the accuracy, completeness, or usefulness of any information, apparatus, product, or process disclosed, or represents that its use would not infringe privately owned rights. Reference herein to any specific commercial product, process, or service by trade name, trademark, manufacturer, or otherwise does not necessarily constitute or imply its endorsement, recommendation, or favoring by the United States Government or any agency thereof, or Battelle Memorial Institute. The views and opinions of authors expressed herein do not necessarily state or reflect those of the United States Government or any agency thereof.

\author{
PACIFIC NORTHWEST NATIONAL LABORATORY \\ operated by \\ BATTELLE \\ for the \\ UNITED STATES DEPARTMENT OF ENERGY \\ under Contract DE-AC05-76RL01830
}

Printed in the United States of America
Available to DOE and DOE contractors from the Office of Scientific and Technical Information,
P.O. Box 62, Oak Ridge, TN 37831-0062;
ph: (865) 576-8401
fax: $(865)$ 576-5728
email: reports@adonis.osti.gov

\begin{abstract}
Available to the public from the National Technical Information Service, U.S. Department of Commerce, 5285 Port Royal Rd., Springfield, VA 22161 ph: (800) 553-6847 fax: $(703) 605-6900$ email: orders@ntis.fedworld.gov online ordering: http://www.ntis.gov/ordering.htm
\end{abstract}

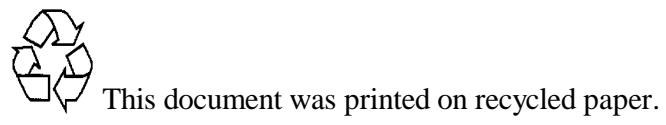




\title{
Simulating Potential Switchgrass Production in the United States
}

\author{
Allison M. Thomson*1, R. César Izarrualde' ${ }^{1}$, Tristram 0. West ${ }^{2}$, David J. Parrish ${ }^{3}$, \\ Donald D. Tyler ${ }^{4}$, Jimmy R. Williams ${ }^{5}$
}

December 2009

${ }^{1}$ Joint Global Change Research Institute, Pacific Northwest National Laboratory and the University of Maryland, 8400 Baltimore Ave., Suite 201, College Park, MD 20740.

2 Environmental Sciences Division, Oak Ridge National Laboratory, PO Box 2008, Oak Ridge, TN, 37831-6335.

3 Virginia Polytechnic Institute, Crop \& Soil Environmental Sciences, 330 Smyth Hall (0404), Blacksburg, VA 24061.

${ }^{4}$ University of Tennessee Experiment Station, Biosystems Engineering and Soil Science, 605 Airways Blvd., Jackson, TN 38301.

${ }^{5}$ Blackland Research Center, 720 E. Blackland Rd, Temple, TX 76502.

*For further information contact Allison Thomson (allison.thomson@pnl.gov; phone 301-314-6750) 


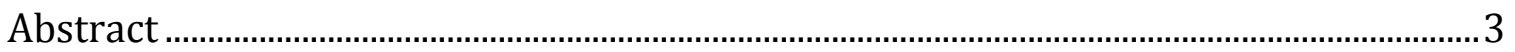

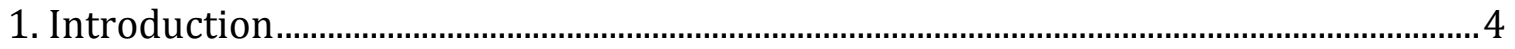

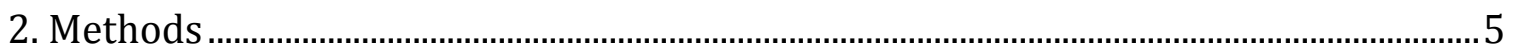

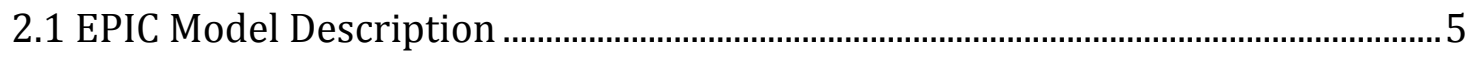

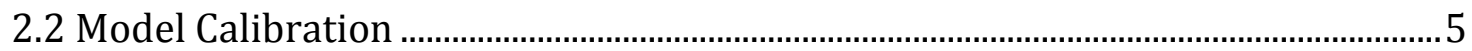

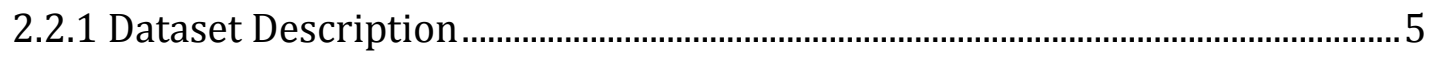

2.2.2 Model Parameter Calibration............................................................................. 6

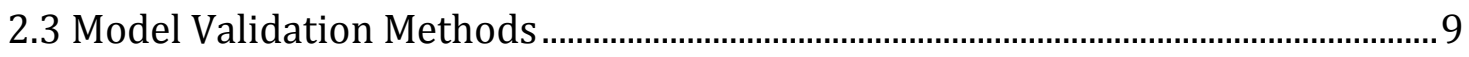

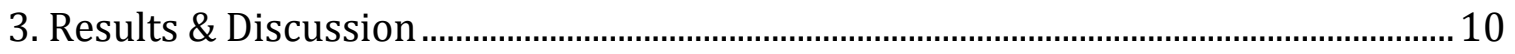

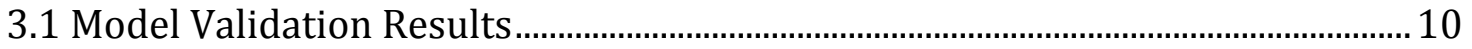

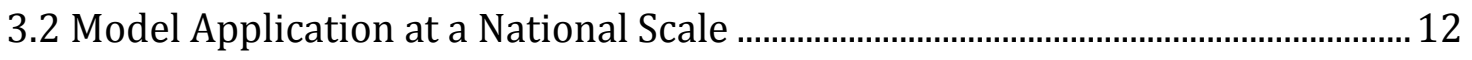

3.3 Further Research: Field Trials and Model Development......................................... 15

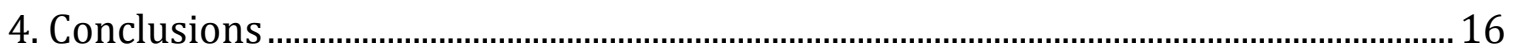

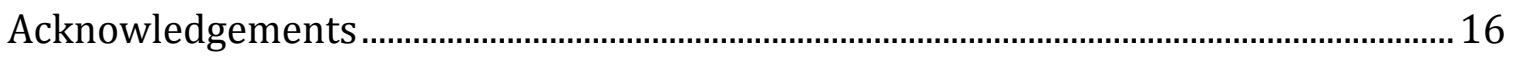

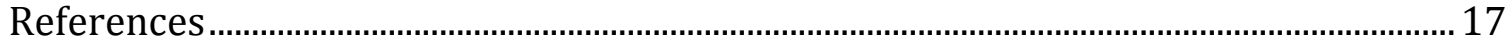




\begin{abstract}
Using results from field trials of switchgrass (Panicum virgatum L.) in the United States, the EPIC (Environmental Policy Integrated Climate) process-level agroecosystem model was calibrated, validated, and applied to simulate potential productivity of switchgrass for use as a biofuel feedstock. The model was calibrated with a regional study of 10-yr switchgrass field trials and subsequently tested against a separate compiled dataset of field trials from across the eastern half of the country. An application of the model in a national database using 8-digit watersheds as the primary modeling unit produces 30 -yr average switchgrass yield estimates that can be aggregated to 18 major watersheds. The model projects average annual switchgrass productivity of greater than $7 \mathrm{Mg} \mathrm{ha}^{-1}$ in the Upper Mississippi, Lower Mississippi, and Ohio watersheds. The major factors limiting simulated production vary by region; low precipitation is the primary limiting factor across the western half of the country, while moderately acidic soils limit yields on lands east of the Mississippi River. Average projected switchgrass production on all crop land in the continental US is $5.6 \mathrm{Mg} \mathrm{ha}^{-1}$. At this level of productivity, 28.6 million hectares of crop land would be required to produce the 16 billion gallons of cellulosic ethanol called for by 2022 in the 2007 Energy Independence and Security Act. The model described here can be applied as a tool to inform the land-use and environmental consequences of switchgrass production.
\end{abstract}




\section{Introduction}

Bioenergy has emerged as an energy supply option with the potential to reduce greenhouse gas emissions and reduce dependence on fossil fuels while providing economic benefit to farmers [1,2]. Cellulosic feedstocks have been identified as a principal component in the bioenergy portfolio by the US Department of Energy [3]. Proposed sources of cellulosic material that can be used for bioenergy include agricultural and forestry residues, mixed grasslands, forests, and monocultures of herbaceous species such as switchgrass (Panicum virgatum L.) and Miscanthus (Miscanthus x giganteus).

Switchgrass meets many of the requirements for a bioenergy crop [4,5]; it is a native (non-invasive), non-food plant species with perennial growth habit that shows a relatively high yield potential with relatively low nutrient requirements. Switchgrass is a warm-season $\left(\mathrm{C}_{4}\right)$ perennial grass native to much of the eastern two-thirds of North America [6] that has been adapted as a forage crop [7-9]. In principle, switchgrass stands may bring environmental benefits such as erosion control, reduced runoff, and nutrient retention [10]. These beneficial effects are evident when using switchgrass in riparian buffer zones [11]. When grown on a large scale as a bioenergy crop, switchgrass may provide a positive net energy balance [12]; however, recent concerns about the emissions of greenhouse gases from conversion of lands to produce crops for biofuels production [13] highlight the need to more fully understand the full carbon balance and environmental consequences of growing bioenergy crops on a large scale. In addition, recent increases in global food prices and food insecurity have been attributed in part to the diversion of food crops for biofuels [14]. Thus, there is a need to examine the sustainability of switchgrass as a bioenergy crop from perspectives of land-use change, biomass productivity, economic return, water and nutrient balances, net greenhouse gas emissions, and biodiversity.

Simulation models of agricultural systems can be applied at a variety of scales to examine the environmental impacts of converting land to biofuel crops and the potential productivity of these crops. Many biophysical models can simulate production for a range of agricultural, grassland, and forestry applications; however, switchgrass and other native grasses have not been widely incorporated into these models. Objectives of this research were to 1) calibrate parameters in the Environmental Policy Integrated Climate model (EPIC) [15] for simulation of switchgrass production, 2) validate the model with an independent dataset, and 3) develop national estimates of potential switchgrass yields for the United States. A national map of potential yields provides a basis for evaluating future potential switchgrass production. We describe model calibration and validation here, illustrate the gradient of national switchgrass yields, discuss differences in US yields, and suggest research needs concerning field trials and modeling. 


\section{Methods}

\subsection{EPIC Model Description}

EPIC is a daily time-step terrestrial ecosystem model capable of simulating a wide array of managed and unmanaged ecosystem processes including plant growth, crop yields, plant competition, and soil erosion as well as heat, water, and nutrient balances [15]. Daily plant biomass gains in EPIC are proportional to the daily photosynthetically active radiation intercepted by the plant canopy. These daily gains in aboveground biomass are affected by vapor pressure deficits, atmospheric $\mathrm{CO}_{2}$ concentration $[16,17]$, and other physiological stresses caused by environmental factors including water, temperature, N, P, and soil aeration. Similarly, daily root growth may be affected by non-optimal values of bulk density, temperature, and aluminum content [18]. Currently, EPIC can simulate about 100 plant species including many crops, native grasses, and trees. Daily weather can be estimated from precipitation, air temperature, solar radiation, wind, and relative humidity parameters or it can be input from historical records. Soil information on horizon depth, texture, bulk density, and C concentration also drives EPIC. EPIC ver.0509, used here, incorporates a soil-C module that allows for a complete calculation of the C-balance including water and wind erosion [19]. Detailed management allows for daily control of the tillage, irrigation, and fertilizer applications.

Initially developed by USDA in the 1970s to evaluate the role of erosion on crop productivity, EPIC has been continually improved and expanded for many research purposes [20]. As a simulation model of not only crop productivity but also the resulting nutrient runoff, wind and water erosion, and soil C dynamics, EPIC is uniquely suited for assessing environmental consequences of land-use change. The model has been applied at regional $[21,22]$ and national scales $[23,24]$ for assessment of climate variability and change impacts on agricultural productivity and for assessments of nutrient dynamics and soil C. Izaurralde et al. [25] used EPIC to evaluate the role of erosion and decomposition on landscape-scale soil C balance, and found clear relationships between land management and the erosion, soil $\mathrm{C}$, and full C balance of small watersheds. Brown et al. [21] applied an earlier version of EPIC to simulate switchgrass response to climate change in the central United States. Since that time, model improvements have been made and additional results from field trials have become available, improving understanding of switchgrass growth and providing a basis for crop modeling improvements.

\subsection{Model Calibration}

\subsubsection{Dataset Description}

Two major ecotypes, or forms, of switchgrass are distinguished based on morphological characteristics [10]. Lowland ecotype varieties are coarser, taller, 
and generally better adapted to the longer, warmer growing seasons of the southern United States; and upland forms are distinguished by their finer textures, earlier maturity, and greater cold tolerance [26]. A 10-yr study at seven locations across the Southeast $[27,28]$ that included both ecotypes was selected as the calibration dataset. The study locations (Table 1) represent a range of soil and climate characteristics. At each site, two plots each of lowland and upland ecotypes were established in 1992. Harvests of this split-plot study occurred in two patterns: either only once in late fall (one-cut management), or in mid-summer and again in late fall (two-cut management). Soil data collected at the time of switchgrass establishment were used, while daily weather records for each study location were obtained from the National Climate Data Center for the simulation period. See Fike et al. $[27,28]$ for more details of the 10-yr study.

Table 1: Site information for the seven locations in the calibration dataset.

\begin{tabular}{|c|c|c|c|c|c|c|c|}
\hline \multirow[t]{2}{*}{ Location } & Switchgrass & Latitude & Elevation & Soil Series & \multicolumn{3}{|c|}{ Annual Weather } \\
\hline & $\begin{array}{l}\text { Lowland } \\
M g h a^{-1}\end{array}$ & & $m$ & & $\begin{array}{c}\text { Average } \\
\text { Max T } \\
{ }^{\circ} \mathrm{C}\end{array}$ & $\begin{array}{c}\text { Average } \\
\text { Min T } \\
{ }^{\circ} \mathrm{C}\end{array}$ & $\begin{array}{c}\text { Total } \\
\text { Precipitation } \\
\mathrm{mm}\end{array}$ \\
\hline $\begin{array}{l}\text { Blacksburg, } \\
\text { VA }\end{array}$ & 11.2 & 37.18 & 600 & $\begin{array}{c}\text { Shottower } \\
\text { loam variant }\end{array}$ & 17.4 & 5.1 & 937 \\
\hline $\begin{array}{l}\text { Jackson, } \\
\text { TN }\end{array}$ & 9.7 & 35.62 & 120 & $\begin{array}{l}\text { Deanburg } \\
\text { silt loam }\end{array}$ & 21.2 & 9.9 & 1335 \\
\hline $\begin{array}{l}\text { Knoxville, } \\
\text { TN }\end{array}$ & 15.9 & 35.88 & 250 & $\begin{array}{c}\text { Etowah } \\
\text { loam }\end{array}$ & 20.7 & 9.4 & 1267 \\
\hline $\begin{array}{l}\text { Morgantown, } \\
\text { WV }\end{array}$ & 12.9 & 39.62 & 378 & $\begin{array}{l}\text { Dormont silt } \\
\text { loam }\end{array}$ & 17.3 & 6.3 & 1068 \\
\hline $\begin{array}{l}\text { Orange, } \\
\text { VA }\end{array}$ & 11.9 & 38.22 & 156 & $\begin{array}{l}\text { Davidson } \\
\text { clay }\end{array}$ & 18.8 & 7.5 & 1101 \\
\hline $\begin{array}{l}\text { Princeton, } \\
\text { KY }\end{array}$ & 12.4 & 37.10 & 173 & Tilsit series & 21.2 & 8.9 & 1261 \\
\hline $\begin{array}{l}\text { Raleigh, } \\
\text { NC }\end{array}$ & 11.6 & 35.72 & 120 & $\begin{array}{l}\text { Cecil sandy } \\
\text { loam }\end{array}$ & 21.8 & 9.6 & 1140 \\
\hline
\end{tabular}

\subsubsection{Model Parameter Calibration}

Initial runs of switchgrass were made incorporating key parameters from the ALMANAC model [29-31], a model closely related to EPIC. Sensitivity analysis of crop-growth parameters in EPIC (data not shown) led to identification of the major factors limiting switchgrass growth. Accordingly, adjustments were made to parameters that factor in 1 ) the timing of leaf decline (DLAI ${ }^{1}=0.75$ (lowland); DLAI $=0.7$ (upland)), 2) the fraction of the growing season where maximum leaf area

\footnotetext{
${ }^{1}$ Acronyms in this paragraph are variable names used in the EPIC code. See Williams [15] for full descriptions and model equations.
} 
occurs, (LAP2 $=50.95), 3$ ) the maximum leaf area index (DMLA = 6 (lowland); DMLA $=3$ (upland) $), 4)$ leaf area decline after anthesis $(\operatorname{RLAD}=0.1), 5)$ the rate of decline in biomass energy after anthesis $(\mathrm{RBMD}=0.1)$, and 6$)$ root weight at plant emergence (RWP1 $=0.4$ ) and plant maturity (RWP2 $=0.3$ ). In addition to plant growth parameter modifications, adjustment was made to the parameter controlling the conversion of standing live biomass to standing residue (PARM66 $=0.001$ ) and residue management. In addition to these and other parameters, plant growth and development in EPIC is influenced by the temperature during the growing season, expressed within the model as "heat units" [15]. The heat units accumulate throughout the growing season, and the value necessary for the crop to reach maturity varies by latitude. In the calibration, heat units required for maturity of switchgrass were automatically determined within EPIC.

Measured yields from all study plots at the seven field trial locations were averaged across the four main treatments (lowland, one-cut; lowland two-cut; upland onecut; upland two-cut) and compared to simulated yields. While the correlation across sites within each management treatment is not strong (Fig. 1) $\left(R^{2}=0.41\right)$, the results are consistent with the findings from these field trials $[27,28]$. The model successfully captures the range of yield across the locations and the differences in yield between upland and lowland ecotypes. The difference in yield between oneand two-cut managements is apparent in the results, with the upland ecotypes being more responsive to the two-cut management. This was observed by Fike et al. $[27,28]$ and attributed to the earlier flowering (which halts vegetative growth) of these upland ecotypes.

The model also adequately captures the current understanding of soil organic $\mathrm{C}$ (SOC) dynamics under switchgrass. An analysis at these field trial locations by Garten and Wullschleger [32] found that SOC was not significantly different under switchgrass, row crops, and grass plant covers at these locations five years after switchgrass establishment. However, stable isotope analysis indicates that SOC response to a conversion to switchgrass will depend on initial SOC levels and management [33]. Simulations of SOC change with EPIC (Fig. 2) are in agreement with these findings, projecting SOC accumulation under soils with low initial C content in the top $30-\mathrm{cm}$ of soil $\left(<40 \mathrm{Mg} \mathrm{C} \mathrm{ha}^{-1}\right)$, higher rates of accumulation under lowland ecotypes, and a dynamic SOC response to cutting management. 


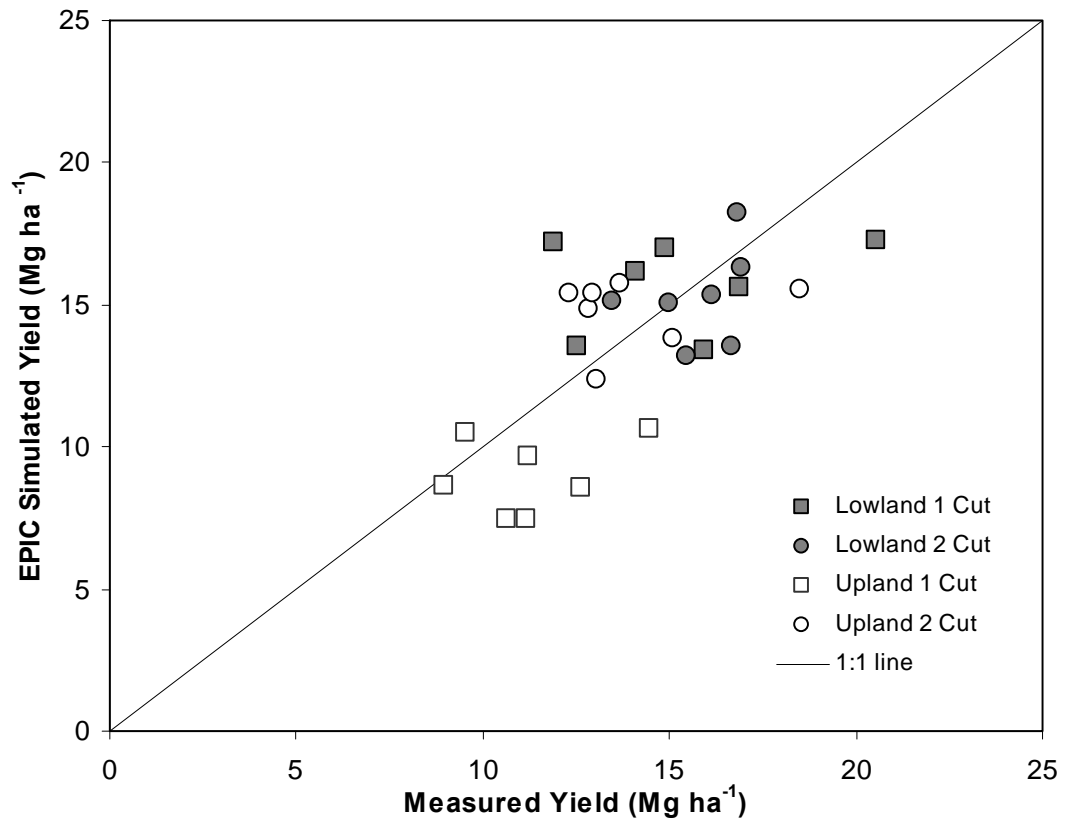

Figure 1: Simulated average switchgrass yields from the model calibration compared with measured yields from 1994-2001 at seven locations, for two ecotypes and two harvest managements.

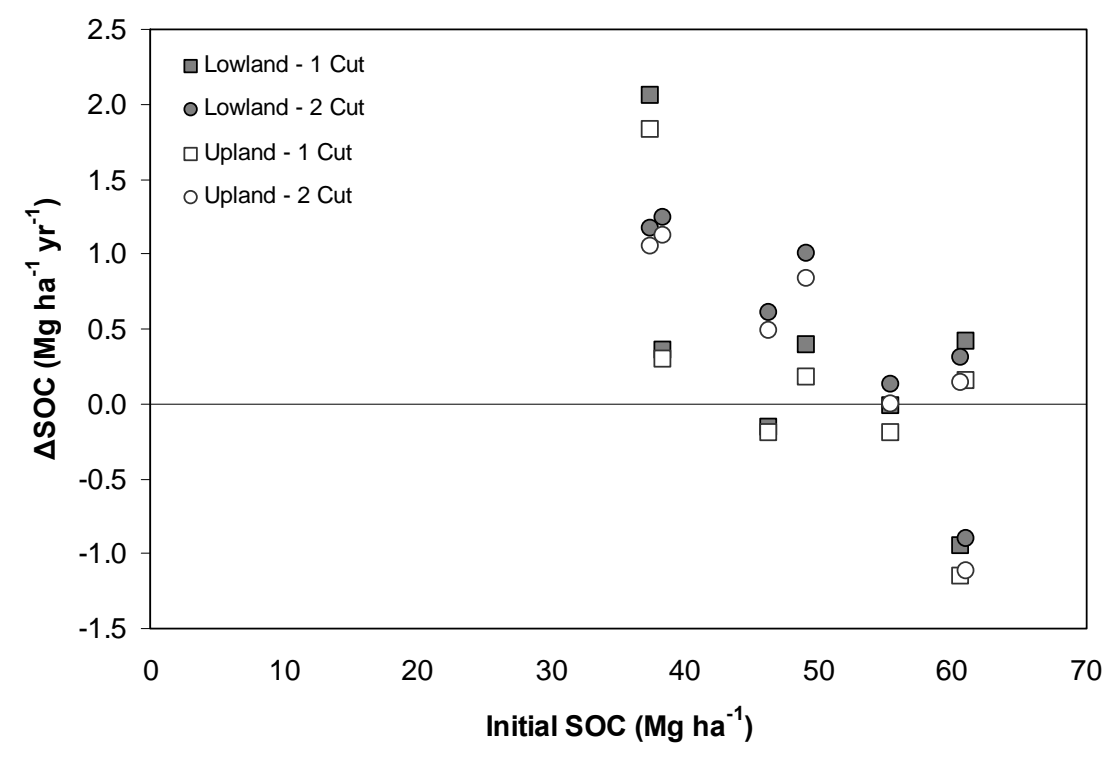

Figure 2: Simulated annual change in soil organic C (SOC) to 30-cm depth as related to initial soil $\mathrm{C}$ levels at the seven calibration dataset locations in the upper southeastern United States. 
The observed variation across sites may be a function of several contributing factors including differences in elevation, site-specific management (e.g. different dates for first harvest), and the interaction of site-specific environmental characteristics with genotype, leading to differences in phenotypic expression. Wide variation in switchgrass yields within a field has been reported observationally for many field trials and has been quantified by Di Virgilio et al. [34], who measured yields ranging from 3 to $20 \mathrm{Mg} \mathrm{ha}^{-1}$ within a 5-ha field The spatial variation was statistically attributed to numerous soil and nutrient characteristics, most significantly nitrogen and phosphorous levels and soil $\mathrm{pH}$. The calibrated model captures the explainable variation in yields and represents the best understanding of switchgrass productivity at this time.

\subsection{Model Validation Methods}

Following initial model calibration, the methods and parameters were applied in EPIC for simulation of an independent data set of field trials. Data from field trials were compiled at Oak Ridge National Laboratory (ORNL) from the peer-reviewed literature and from direct communication with field researchers [35]. These data represent 31 field trial locations with 1400 data points. Each data point includes information on yields, management, and production inputs. These data provided an independent test of the EPIC model over a wider geographic range and set of growing conditions.

From the full dataset, 67 cases representing field trial results from 10 states and a variety of fertilization and harvest practices were simulated. Cases were selected for validation if they had two or more years of recorded yield, represented one- or twocut management, and were grown without irrigation. Sites from the Fike et al. $[27,28]$ study were used in the model calibration and therefore not considered in the validation. Input data for the model consisted of management details from the field trial database, soil profile information for the database-specified soil type from the state soil survey database STATSGO [36], and long-term climatology for each location. By using soils and weather data that are available nationally rather than site-specific, this simulation test informs the validity of extending EPIC switchgrass simulations beyond field sites to regional scales.

An additional purpose of the validation was to establish heat-unit scheduling for management operations. This is necessary for simulations where perfect information on crop management is not available, and for simulations that extend the model to new regions where specific field management practices have not yet been established. Based on the known management and model-generated heat-unit values from the calibration dataset, each planting, harvest and fertilizer operation in the model validation was assigned a time to occur relative to crop maturity. Those established values then allow the model to automatically schedule management operations in the validation simulations. Use of heat-unit scheduling allows EPIC to account for variation in growing season timing and duration by automatically 
scheduling the date of each planting, harvest and fertilizer operation based on temperature during the growing season.

\section{Results \& Discussion}

\subsection{Model Validation Results}

Similar to the calibration dataset, a confounding factor in the validation simulations was the wide variation in measured switchgrass yields even within locations. Statistical analysis of the field trial dataset by Gunderson et al. [35] found considerable variability in switchgrass yield. They found that yields were more highly correlated with temperature and precipitation than management (e.g. N application, number of harvests) or environmental parameters (e.g. soil texture class). Lowland ecotypes consistently had higher reported yield than upland ecotypes.

EPIC results show a good fit of simulated to observed yield for lowland ecotypes, with some over-prediction of upland ecotype yields (Fig. 3). EPIC simulated a narrower range of yields for two-cut management than was evident in the observed yields, reflecting the strong influence of weather variability within the growing season and the importance of the exact date of the first harvest. Both the observed and simulated yields of upland ecotypes did not show significantly higher total annual yield with an additional harvest in the two-cut management.

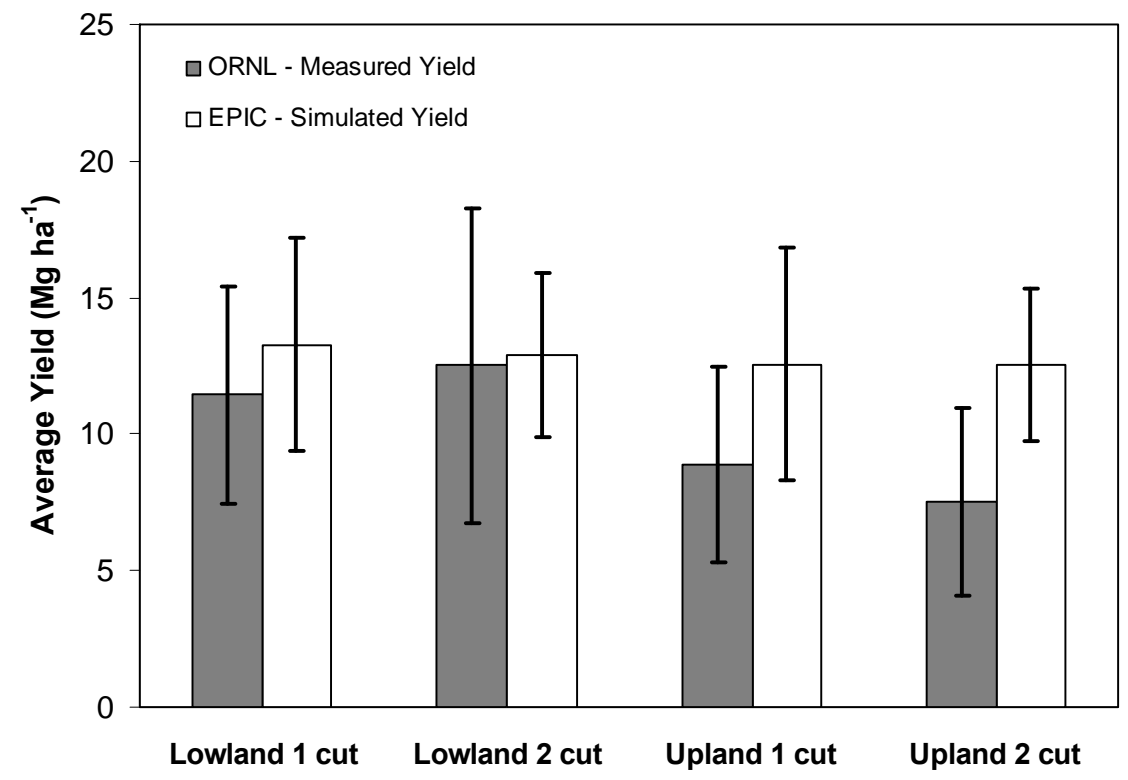

Figure 3: Annual average and range (solid line) of measured and simulated yields by ecotype and harvest management for 67 field trials in the validation dataset. Vertical lines represent the full range of measured and simulated yield. 
The average and range of simulated and measured yield as grouped by state (Fig. 4) demonstrates the range of yields across the geographic extent of the field trials. EPIC slightly overestimates measured switchgrass yields, particularly for states where few field trials were available for comparison (e.g. Arkansas, South Dakota). One variable with significant variation in the field trial dataset was $\mathrm{N}$ application. Both simulated and measured yield response to $\mathrm{N}$ application rate (Fig. 5) showed a yield response to $\mathrm{N}$ at rates up to $100 \mathrm{~kg} \mathrm{ha}^{-1} \mathrm{yr}^{-1}$ and little yield response to $\mathrm{N}$ application rates above $200 \mathrm{~kg} \mathrm{ha}^{-1} \mathrm{yr}^{-1}$. This finding is consistent with studies that recommended application rates of less than $100 \mathrm{~kg} \mathrm{ha}^{-1} \mathrm{yr}^{-1}$ as adequate for switchgrass production in most cases [35,5].

a) Measured yields

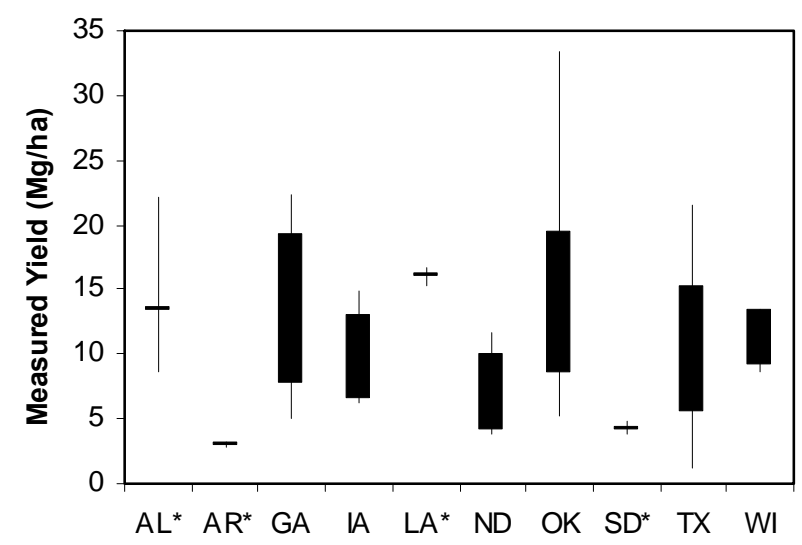

b) EPIC simulated yields

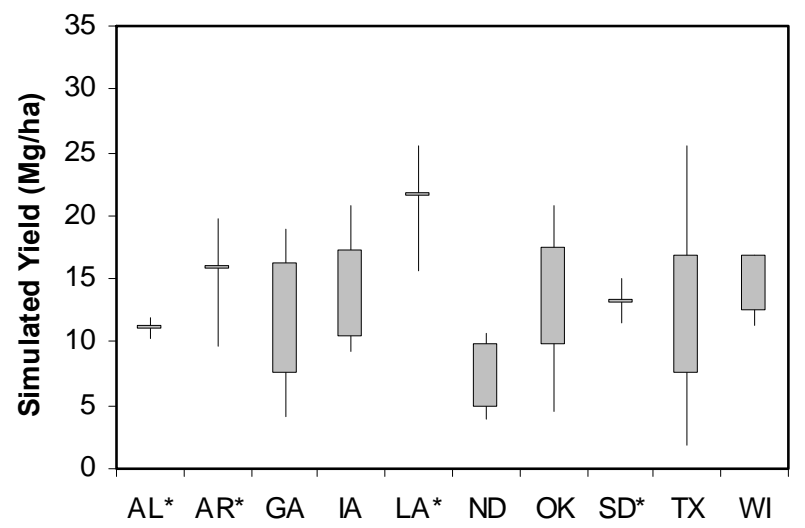

*States with too few records for standard deviation

Figure 4: Switchgrass a) measured and b) simulated yields by state for 67 field trials in the validation dataset. Solid box represents one standard deviation from the mean, and solid line represents full range of yield. 
a) Measured yield

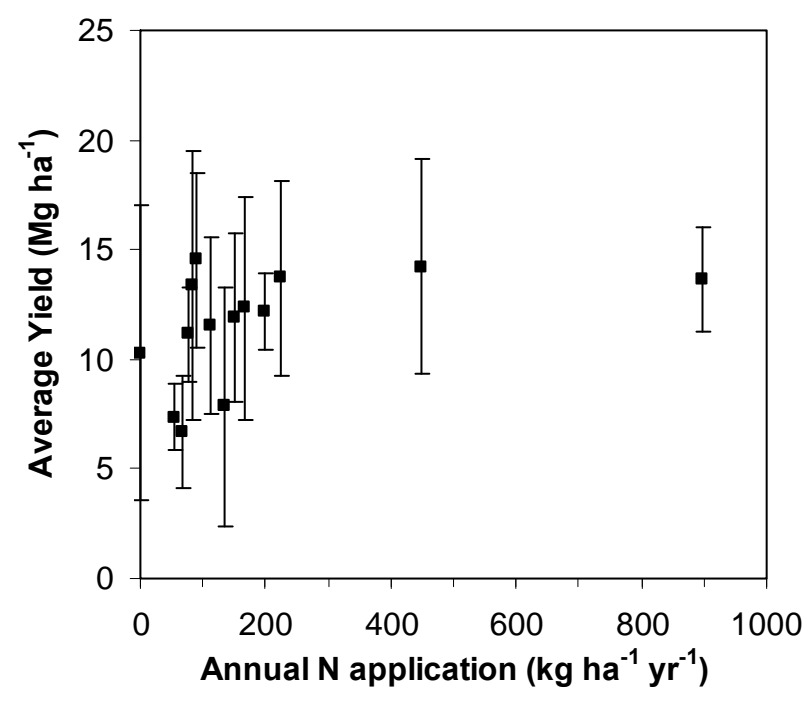

b) EPIC simulated yield

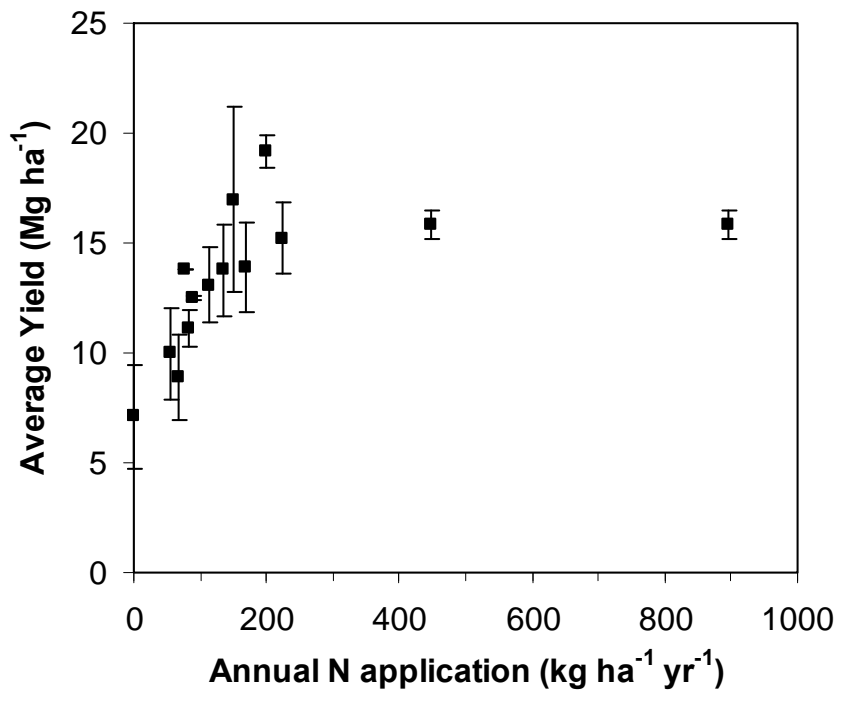

Figure 5: Average (point) and range (line) of a) measured and b) simulated switchgrass yields to $\mathrm{N}$ application at 22 validation dataset field trial locations nationwide.

\subsection{Model Application at a National Scale}

Based on findings and model improvements from the calibration and validation described above, EPIC was applied to simulate long-term yields of switchgrass for the continental United States. Lowland ecotypes were simulated for all lands south of $41^{\circ} \mathrm{N}$, while upland ecotypes were simulated for the northern tier of the country. The modeling datasets applied here [24,37] delineate modeling units based on 
hydrologic unit area classification (USGS) at the 8-digit and 4-digit level, respectively. Major agricultural lands were simulated at the 8-digit level, with multiple agricultural soils representing a minimum of $70 \%$ of the variability of soils within each modeling unit. Simulations for each modeling unit were for 30-year periods based on long-term average climatology for the modeling unit. Planting and harvest dates of switchgrass were adjusted based on long-term climatology and EPIC heat-unit scheduling.

The resulting model estimates are not predictions of yield at any specific location; rather they are a projection of the potential for switchgrass growth in the regions represented by the modeling unit. Yields are averaged over the 30-year simulation, and range from a high of $16 \mathrm{Mg} \mathrm{ha}^{-1}$ in eastern Texas and Oklahoma and parts of Louisiana and Florida to a low of less than $2 \mathrm{Mg} \mathrm{ha}^{-1}$ across much of the land in Utah, Nevada, and Arizona (Fig. 6). When the results are aggregated to 18 major watershed regions, the highest average yields occur in the Lower Mississippi region, with averages above $7 \mathrm{Mg} \mathrm{ha}^{-1}$ in the Ohio and Upper Mississippi Regions (Table 2). The high maximum yield in the South Atlantic-Gulf region is attributed to simulation of switchgrass on organic soils in Florida, which is also apparent in Fig. 6. In comparison, Brown et al. [21] simulated switchgrass yields of similar magnitude for sites in Missouri, Iowa, Nebraska, and Kansas, with highest average yields of 9 to 10 $\mathrm{Mg} \mathrm{ha}^{-1}$ in central Iowa and Missouri, declining to 4 to $6 \mathrm{Mg} \mathrm{ha}^{-1}$ in western Kansas and Nebraska.

Table 2: Average and maximum switchgrass yield by major United States region from over 7700 30-yr simulations with EPIC.

\begin{tabular}{lcc}
\hline \multirow{2}{*}{ Region } & \multicolumn{2}{c}{$\begin{array}{c}\text { Switchgrass Yield } \\
\left(\mathrm{Mg} \mathrm{ha}^{-1}\right)\end{array}$} \\
\hline & Average & Maximum \\
\cline { 2 - 3 } New England & 4.1 & 10.1 \\
Mid-Atlantic & 4.1 & 11.8 \\
South Atlantic-Gulf & 6.3 & 25.3 \\
Great Lakes & 6.2 & 10.2 \\
Ohio & 7.0 & 15.5 \\
Tennessee & 6.7 & 14.5 \\
Upper Mississippi & 7.1 & 14.2 \\
Lower Mississippi & 7.4 & 14.5 \\
Souris-Red-Rainy & 4.6 & 7.8 \\
Missouri & 4.9 & 16.7 \\
Arkansas-White-Red & 5.9 & 17.5 \\
Texas Gulf & 6.4 & 16.7 \\
Rio Grande & 2.6 & 8.6 \\
Upper Colorado & 1.7 & 5.4 \\
Lower Colorado & 1.4 & 4.4 \\
Great Basin & 1.5 & 4.4 \\
Pacific Northwest & 2.7 & 8.2 \\
California & 2.5 & 6.1 \\
\hline
\end{tabular}




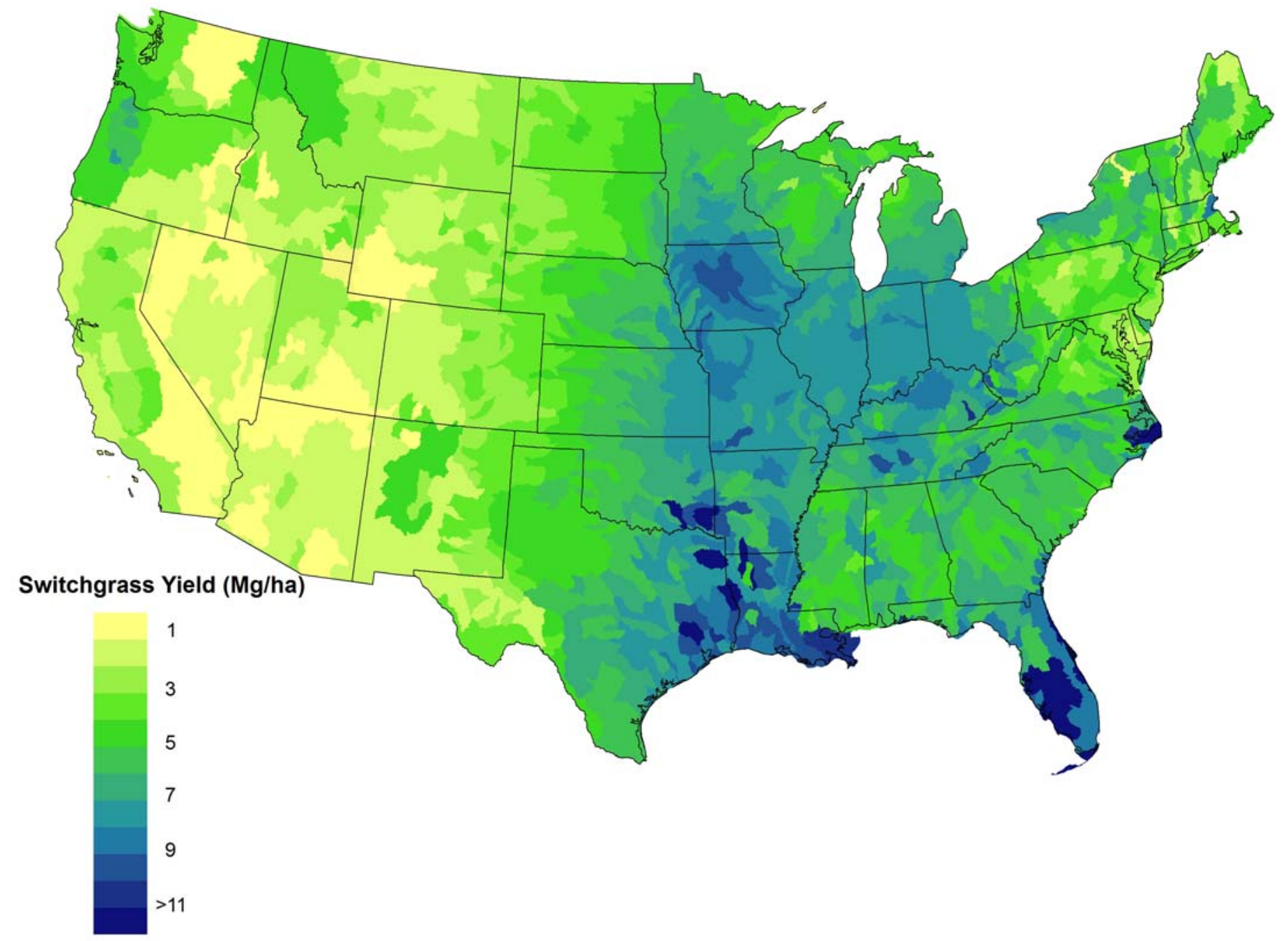

Figure 6: Simulated potential 30-yr average switchgrass yields for lowland and upland (north of $41^{\circ} \mathrm{N}$ ) ecotype with one harvest per year. 
Statistical analysis informs the source of variation in yields within each of the 18 major watershed regions. In a multiple stepwise regression (PROC REG in SAS statistical software) [38], variation in switchgrass yield at the regional scale was found to be, on average, $76 \%$ attributable to a combination of soil properties, temperature, precipitation, and latitude. Precipitation was found to be the dominant determinant of yields in regions west of the Mississippi River with partial $\mathrm{R}^{2}$ ranging from 0.57 to 0.87 . The exception was for the Upper Mississippi region, where soil texture was the primary determinant $\left(\mathrm{R}^{2}=0.38\right)$ of upland switchgrass yield, while topsoil depth was the primary determinant of lowland yield $\left(\mathrm{R}^{2}=0.62\right)$. Along the East and Gulf Coastal plains, simulated yields are primarily determined by soil $\mathrm{pH}$, with partial $\mathrm{R}^{2}$ ranging from 0.43 to 0.79 . Lower soil $\mathrm{pH}$ has a negative effect on simulated yield in the Mid-Atlantic region and the Gulf Coast states (Fig. 6). In these regions, low organic matter content and less buffering of aluminum and manganese contribute to the sensitivity to soil acidity. While research has shown that switchgrass can be effectively established and grown on acidic soils [39], productivity is improved by liming $[40,41]$, indicating that low $\mathrm{pH}$ may limit the potential production of switchgrass.

While our results indicate that switchgrass can be grown in many diverse areas across the United States, the highest potential productivities are in regions that are also the highest producing agricultural lands in the country. This indicates that potential conflict between food production and large scale switchgrass production will need to be carefully considered. The average long-term simulated switchgrass yield on land classified as crop land [24] is $5.6 \mathrm{Mg} \mathrm{ha}^{-1}$.

The 2007 Energy Independence and Security Act calls for an annual production of 15.2 billion gallons of renewable fuels by 2012 and 36.0 billion gallons by 2022 . Of these totals, 0.5 billion gallons (3.2\%) in 2012 and 16 billion gallons (45\%) in 2022 are mandated to be produced as cellulosic ethanol. Assuming a conversion rate of 0.38 liters of ethanol from $1 \mathrm{~kg}$ of biomass [12], the model projections indicate this goal would require conversion of 0.9 million ha of current crop land to switchgrass production in 2012. In 2022, a total of 28.6 million ha of crop land - $23 \%$ of total US cropland - would be required to meet the targeted production.

\subsection{Further Research: Field Trials and Model Development}

EPIC and other models will continue to be improved with results from field trials and research on switchgrass and other crops with bioenergy feedstock potential. By establishing the most accurate model possible now, the bioenergy research community can begin exploring the potential for and environmental consequences of large-scale switchgrass production. We demonstrate model application to a dataset representing agricultural lands. Additional regional scale simulations of non-agricultural land could inform decisions about locations for switchgrass production. 
Switchgrass is native to much of North America but has only recently begun to be developed for large-scale energy cropping [5]; therefore, there remains substantial genetic variation as well as observed differences in phenotypic expression that are not yet possible to capture in a crop model. The model does successfully capture the explainable differences between upland and lowland ecotypes, but limitations remain. With further research on plant growth and a reduction in the uncertainty of the causes of the observed yield variability, any number of cultivars of switchgrass can be simulated in crop models.

This study highlights some of the variables for which further agronomic research and field trials will be valuable to crop modeling. Measurements of leaf area throughout the growing season, switchgrass yield response to liming, and soil C change under switchgrass following conversion from crop, grass, or forest land would all be valuable. In addition, full reporting of the management used to achieve reported yields, including management for weed control, nutrient applications, and residue management would assist in reducing uncertainty in model simulations.

\section{Conclusions}

Here the EPIC model has been calibrated with and validated against field trials representing switchgrass production across a wide geographic scope. While the model successfully captures the explainable yield variability, there are some apparent determinants of switchgrass yield that are unaccounted for in the known details of the field trials. Studies considering soil pH effects on switchgrass growth in the past have found that, while switchgrass is tolerant of a wide range of $\mathrm{pH}$, low $\mathrm{pH}$ negatively affects productivity. The field trials used here were not designed to consider varying levels of $\mathrm{pH}$, yet the findings from on the process-based model illustrate the importance of soil acidity as a factor in productivity, particularly in the East and Gulf Coastal Plain regions.

The model described here can now be applied with a known level of confidence to examine potential production of switchgrass as well as the land-use requirements and environmental consequences of large-scale production. Simulations of switchgrass over the continental United States indicate the relative productivity of switchgrass in different regions and the scope of the land-use change that may potentially be required to meet national renewable fuel production objectives.

\section{Acknowledgements}

We thank J.R. Kiniry of USDA for model guidance and C.T. Garten of ORNL for access to data. This work was supported by the US Department of Energy, Office of Science through the Center for Carbon Sequestration in Terrestrial Ecosystems and the Integrated Assessment Research Program. Collection and analysis of data at ORNL for the validation data was supported by the US Department of Energy, Office of Biomass Program. 


\section{References}

[1] Paine LK, Peterson TL, Undesander DJ, Rineer KC, Bartlet GA, Temple SA, Sample DW, Klemme RM. Some ecological and socio-economic considerations for biomass energy crop production. Biomass and Bioenergy 1996; 10(4):231-242.

[2] McLaughlin SB, Kiniry JR, Taliaferro CM, de la Torre Ugarte D. Projecting yield and utilization potential of switchgrass as an energy crop. Adv. Agro. 2006; 90:267-297.

[3] US Department of Energy. Breaking the biological barriers to cellulosic ethanol: A joint research agenda. DOE/SC-0095. US Department of Energy, Office of Science and Office of Energy Efficiency and Renewable Energy 2006.

[4] Fike JH, Parrish DJ, Alwang J, Cundiff JS. Challenges for deploying dedicated, large-scale, bioenergy systems in the USA. CAB Reviews 2007; 2(064):1-28.

[5] Parrish DJ, Fike JH, Bransby DI, Samson R. 2008. Establishing and managing switchgrass as an energy crop. Forage \& Grazinglands; 2008. doi:10.1094/FG2008-0220-01-RV

[6] Knapp AK, Blair JM, Briggs JM, Collins SL, Hartnett DC, Johnson LC, Towne EG. The keystone role of bison in north American tallgrass prairie - Bison increase habitat heterogeneity and alter a broad array of plant, community, and ecosystem processes. BioScience 1999; 49: 39-50.

[7] Krueger CR, Curtis DC. Evaluation of big bluestem, Indiangrass, sideoats grama, and switchgrass pastures with yearling steers. Agron. J. 1979; 71:480-482.

[8] Hall KE, George JR, Riedl RR. Herbage dry-matter yields of switchgrass, big bluestem, and Indiangrass with N-fertilization. Agron. J. 1982; 74:47-51.

[9] Stout WL, Jung GA, Shaffer JA, Estepp R. Soil-water conditions and yield of tall fescue, switchgrass, and Caucasian bluestem in the Appalachian Northeast. J. Soil Water Conserv. 1986; 41:184-186.

[10] Parrish DJ, Fike JH. The biology and agronomy of switchgrass for biofuels. Critical Rev. Plant Sci. 2005; 24:423-459.

[11] Blanco-Canqui H, Gantzer CJ, Anderson SH, Alberts EE, Thompson AL. Grass barrier and vegetative filter strip effectiveness in reducing runoff, sediment, nitrogen, and phosphorus loss. Soil Sci. Soc. America J. 2004; 68:1670-1678. 
[12] Schmer, MR, Vogel KP, Mitchell RB, Perrin RK. Net energy of cellulosic ethanol from switchgrass. Proceedings of the National Academy of Science 2008; 105(2):464-469.

[13] Searchinger T, Heimlich R, Houghton RA, Dong F, Elobeid A, Fabiosa J, Tokgoz S, Hayes D, Yu T. Use of US croplands for biofuels increases greenhouse gases through emissions from land-use change. Science 2008; 319:1238-1240.

[14] von Braun J. Rising Food Prices: What should be done? International Food Policy Research Institute Policy Brief, IFPRI, Washington, DC. April 2008.

[15] Williams JR The EPIC Model. In: Singh VP, editor. Computer Models of Watershed Hydrology. Water Resources Publications, Highlands Ranch, CO. 1995. p 909-1000.

[16] Stockle CO, Williams JR, Jones CA, Rosenberg NJ. A method for estimating the direct and climatic effects of rising atmospheric carbon dioxide on growth and yield of crops. I. Modification of the EPIC model for climate change analysis. Agric. Syst. 1992; 38(3): 225-238.

[17] Stockle CO, Dyke PT, Williams JR, Jones CA, Rosenberg NJ. A method for estimating the direct and climatic effects of rising atmospheric carbon dioxide on growth and yield of crops. II. Sensitivity analysis at three sites in the midwestern USA. Agric. Syst. 1992; 38(3): 239-256.

[18] Jones CA, Bland WL, Ritchie JT, Williams JR. Simulation of root growth. In: Hanks J, Ritchie JT, editors. Modeling Plant and Soil Systems. ASA, CSSA, SSSA Publ., Madison, Wisconsin; 1991, pp. 91-123.

[19] Izaurralde RC, Williams JR, McGill WB, Rosenberg NJ, Quiroga Jakas MC. Simulating soil C dynamics with EPIC: Model description and testing against long-term data. Ecol. Modelling 2006; 192:362-384.

[20] Gassman PW, Williams JR, Benson VR, Izaurralde RC, Hauck LM, Jones CA, Atwood JD, Kiniry JR, Flowers JD. Historical Development and Applications of the EPIC and APEX models. Center for Agricultural and Rural Development, Iowa State University, Ames, Iowa. 05-WP 397. 2005.

[21] Brown RA, Rosenberg NJ, Hays CJ, Easterling WE, Mearns LO. Potential production and environmental effects of switchgrass and traditional crops under current and greenhouse-altered climate in the central United States: a simulation study. Agric. Ecosyst. Environ. 2000; 78: 31-47. 
[22] Thomson AM, Izaurralde RC, Rosenberg NJ, He X. Climate change impacts on agriculture and soil carbon sequestration potential in the Huang-Hai Plain of China. Agric., Ecosyst. Environ. 2006; 114(2-4): 195-209.

[23] Izaurralde RC, Rosenberg NJ, Brown RA, Thomson AM. Integrated assessment of Hadley Center (HadCM2) climate-change impacts on agricultural productivity and irrigation water supply in the conterminous United States Part II. Regional agricultural production in 2030 and 2095. Agric. Forest Meteorol. 2003; 117(12): 97-122.

[24] Potter SR, Atwood JD, Kellogg RL, Williams JR. An approach for estimating soil carbon using the national nutrient loss database. Environ. Management 2004; 33:496-506.

[25] Izaurralde RC, Williams JR, Post WM, Thomson AM, McGill WB, Owens LB, Lal R. Long-term modeling of soil $\mathrm{C}$ erosion and sequestration at the small watershed scale. Climatic Change 2007; 80:73-90.

[26] Casler MD, Vogel KP, Taliaferro CM, Wynia RL. Latitudinal Adaptation of Switchgrass Populations. Crop Science, 2004; 44:293-303

[27] Fike, JH, Parrish DJ, Wolf DD, Balasko JA, Green Jr. JT, Rasnake M, Reynolds JH. Long-term yield potential of switchgrass-for-biofuel systems. Biomass and Bioenergy 2006; 30:198-206.

[28] Fike, JH, Parrish DJ, Wolf DD, Balasko JA, Green Jr. JT, Rasnake M, Reynolds JH. Switchgrass production for the upper southeastern USA: Influence of cultivar and cutting frequency on biomass yields. Biomass and Bioenergy 2006; 30:207213.

[29] Kiniry JR, Williams JR, Gassman PW, Debaeke P. A general process-oriented model for 2 competing plant-species. Trans. ASAE 1992; 35:801-810.

[30] Kiniry JR, Sanderson MA, Williams JR, Tischler CR, Hussey MA, Ocumpaugh WR, Read JC, Van Esbroeck G, Reed RL. Simulating Alamo switchgrass with the ALMANAC Model. Agron. J. 1996; 88:602-606.

[31] Kiniry JR, Cassida KA, Hussey MA, Muir JP, Ocumpaugh WR, Read JC, Reed RL, Sanderson MA, Venuto BC, Williams JR. Switchgrass simulation by the ALMANAC model at diverse sites in the southern US. Biomass and Bioenergy 2005; 29:419125 .

[32] Garten CT, Wullschleger SD. Soil Carbon Inventories under a Bioenergy Crop (Switchgrass): Measurement Limitations. J. Env. Quality 1999; 28(4): 1359-1365. 
[33] Garten CT, Wullschleger SD. Soil Carbon Dynamics beneath Switchgrass as Indicated by Stable Isotope Analysis. J. Env. Quality 2000; 29(2):645-653.

[34] Di Virgilio N, Monti A, Venturi G. Spatial variability of switchgrass (Panicum virgatum L.) yield as related to soil parameters in a small field. Field Crops Research 2007; 101: 232-239.

[35] Gunderson CA, Davis EB, Jager H, Perlack R, West TO, Brandt C, Wullschleger S, Baskaran L, Downing M, Wilkerson E. Exploring Potential U.S. Switchgrass Production for Cellulosic Ethanol Using Empirical Modeling Approaches. Oak Ridge National Laboratory, Oak Ridge, TN. ORNL/TM-2007/183. 2008.

[36] USDA, Soil Survey Staff. U.S. general soil map (STATSGO). USDA Natural Resource Conservation Service, Washington, DC. 1994.

[37] Thomson AM, Rosenberg NJ, Izaurralde RC, Brown RA. Climate Change Impacts for the Conterminous USA: An Integrated Assessment, Part 2, Models and Validation. Climatic Change 2005; 69(1):27-42.

[38] SAS Institute. SAS, Version 9.1. SAS Institute, Cary, NC. 2006.

[39] Hopkins AA, Taliaferro CM. Genetic variation within switchgrass populations for acid soil tolerance. Crop Science 1997; 37: 1719-1722.

[40] Jung GA, Shaffer JA, Strout WL. Switchgrass and big bluestem responses to amendments on strongly acid soil. Agronomy J. 1988; 80(4):669-676.

[41] Bona L, Belesky DP. Evaluation of switchgrass entries for acid soil tolerance. Communications in Soil Science and Plant Analysis 1992; 23(15-16): 1827-1841. 